Tushnova A., Y. (2020). Features of social-perceptual properties of mathematically gifted students, International Journal of Cognitive Research in Science, Engineering and Education (IJCRSEE), (8), Special issue of Current Research and Trends in Cognitive Sciences 2020, 103-112.

Original scientific paper

UDK:

Received: October, 10.2020.

Revised: November, 27.2020.

159.928.072-057.875

Accepted: December, 02.2020 .

doi: 10.23947/2334-8496-2020-8-SI-103-112

\title{
Features of Social-Perceptual Properties of Mathematically Gifted
} Students

\author{
Tushnova A. Yuliya ${ }^{1 *}$
}

\begin{abstract}
'Department of educational psychology and organizational psychology, Don State Technical University, Russian Federation, e-mail: trubulya@yandex.ru
\end{abstract}

\begin{abstract}
The attention of modern society to intellectual potential makes the problem of studying mathematically gifted youth at the stage of self-determination in higher education relevant. Practical problems related to the psychological features of social adaptation of mathematically gifted youth require solving. The main goal of the research is to study the social and perceptual abilities of mathematically gifted students. The study sample consisted of 76 natural science students aged 17-23 years ( $M=19.8, S D=3.2(58 \%$ men). The research methods were: testing (test of analytical mathematical abilities, test of the structure of intelligence (TSI) of R. Amthauer), expert assessment, survey (questionnaire of V. A. Krutetsky, questionnaires aimed at diagnosing socio-perceptual abilities), statistical methods. Self-assessment of intelligence, composite assessment, and some components of social intelligence and some components of empathy are significantly different. The ability of mathematical generalization and practical mathematical thinking have a greater number of relationships with social and perceptual properties. Here we found relationships not only with empathy, but also the ability to recognize verbal expression and the General ability to understand and manage their own and other people's emotions. The ability to operate images in two-dimensional space is related only to the level and components of emotional intelligence. According to the results of the study, the features of socio-perceptual properties of students with different levels of analytical mathematical abilities are described. The conclusions can be used in the development of a program of psychological support for this category of students.

Keywords: mathematical abilities, social-perceptual abilities, giftedness, student age.
\end{abstract}

\section{Introduction}

Research of abilities is closely related to the problem of giftedness, which is relevant today not only for science, but also for the economic and social spheres. Describing current trends, Yurkevich (2009) notes that the technological approach, which understands gifted people as economic capital, arose long ago, where giftedness is associated with innovation, the creation of an economically valuable product, the sum of achievements. This explains the growth of requirements to the intellectual potential of a person, the social order for specialists with individually expressed professional abilities in different types of professions.

Modern researchers describe giftedness as a holistic, multi-level, multi-component and dynamic phenomenon (Bogoyavlenskaya, 2004; Bogoyavlenskaya, 2010; Davidson, 2009; Druzhinin, 2000; Kholodnaya, 2011; Leites, 2008; Ushakov, 2011; Renzulli, 2002, 2005; Ridetskaya, 2011; Sternberg, 2000). Mathematical giftedness, as a type of special intellectual giftedness, is considered in different approaches: research in mathematical giftedness of particular abilities (Krutetsky, 1998), research of the General factor of mathematical giftedness. Namely, the General factor of mathematical giftedness is considered to be the General factor of intelligence, the speed factor of information processing, the level of thinking and mathematical intuition (Kryukova, 2001). Kolmogorov (2001) defines mathematical abilities as integral qualities of the mind. Mathematical abilities, according to the scientist, arise spontaneously in childhood, are specific (analytical, synthetic) and require pedagogical support in social adaptation (Kolmogorov, 2001). In the mod-Delhi of the V. N. intelligent range. Druzhinin the top is a formally-sign object, which is formed last and provides productivity of mathematical activity (Khertanova and Kondaurova, 2006). Krasnoryadtseva (2013) considers the phenomenon of mathematical giftedness as a systemic quality of a person in the context of creative life fulfillment, an individual measure that characterizes the implementation of the translation of their capabilities into reality at specific stages of self-development.

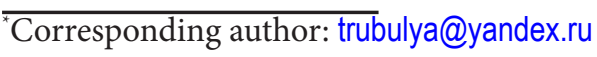

www.ijcrsee.com 
The study of the formation of mathematical abilities is considered from different sides: the role of cognitive, emotional and motivational processes of self-regulation in learning and performing mathematical tasks (Hanin and Van Nieuwenhoven, 2020), mathematical productivity and mathematical anxiety (Ashcraft and Krause, 2007; Ayres, 2001; Sari Faradba et al., 2019), procedural strategies for solving simple and complex problems in different cultures (Campbell et al, 2001), mathematical creativity and mathematical abilities (Schoevers et al, 2020), and much more. Most of the research is devoted directly to mathematical skills and the factors that influence them, as well as describing techniques for improving the effectiveness of teaching mathematics.

In General, research on the problem of mathematical abilities is inextricably linked to the concepts of intelligence, General and special abilities (Bogoyavlenskaya, 2004; Bogoyavlenskaya, 2010; Bogoyavlenskaya and Nizovtsova, 2017; Krutetsky, 1998; Leites, 2008; Ushakov, 2011; Kholodnaya, 2011). Some approaches consider abilities in the structure of General intelligence as a single ability, while others identify specific abilities that are responsible for the successful solution of test problems (Shadrikov, 2019). Describing abilities and talent, scientists say, not only to their complex composition, but also from personal characteristics of value-semantic sphere, creative ispossibly, environmental conditions (Krasnoryadtseva, 2013; Shadrikov, 2019; Yurkevich, 2009).

Shadrikov (2019) notes that giftedness is a dynamic education and can exist at the initial stages of mastering professional activity. Based on the theory that abilities are properties of functional systems that implement individual mental functions, Shadrikov (2019) speaks about the natural giftedness of the individual, the giftedness of the subject of activity and the giftedness of the individual. This understanding allows us to consider mathematical giftedness at the stage of mastering professional activity in higher education. Also, the Kolmogorov (2001) regulation on reducing the effectiveness of social adaptation of mathematically gifted students actualizes practical tasks related to the psychological features of social adaptation of gifted youth. In the process of adaptation, the individual is a participant in communication, an important characteristic of which are social-perceptual properties. Andreeva (2000) understands social perception as an integral process of reflecting the personal properties of another person, the process of knowing the other in terms of communication and joint activities. Kunitsyna, Kazarinova, and Pogol'sha (2001) defines social perception as a process that occurs in interpersonal interaction based on natural communication and occurs in the form of perception and understanding by one person of another. Ryzhov (1981), considering social-perceptual properties from the position of the activity approach, notes that they are associated with the processes of integration of individual participants of joint activity into its aggregate subject.

The explanation of the limits of the level of mathematical abilities associated with the features of social and perceptual properties of students requires generalization of the above views. According to Khinchin (1961), the mathematical orientation of the mind contributes to the formation of a special style of thinking, which is characterized by a formal logical scheme of reasoning, brevity, fragmentation of reasoning, accuracy of symbols (cited in Kanin, 2013). It is important to keep in mind that General intelligence does not indicate mathematical abilities (Kanin, 2013; Shadrikov, 2019). General intelligence is more related to stereotype thinking, and mathematical abilities are more related to creative thinking (Kanin, 2013; Krasnoryadtseva, 2013). That is, the process of social perception itself can be associated with the peculiarities of the type of thinking of people with developed mathematical abilities. The special style of thinking of mathematically gifted people can build the process of knowing another person and working together in a special way.

Ideas about the decrease in the effectiveness of social adaptation of mathematically gifted students (Kolmogorov, 2001), about the possibility of studying giftedness at the early stages of mastering professional activity (Shadrikov, 2019), justify the research interest in the problem of mathematical abilities of students. Ideas about the need to create an environment for developing the abilities of gifted students (Bogoyavlenskaya, 2004; Bogoyavlenskaya, 2010), in this context, requires attention not only to the organization of the learning process in mathematics, but also to the social environment in which students are located. In the process of constructing a social environment for mathematically gifted students, the psychologist will be interested in the features of the socio-perceptual properties of this target category.

Given the idea that mathematical giftedness is associated with personal properties and life fulfillment, in General, the study of the social and perceptual properties of mathematically gifted students will clarify the peculiarities of their communication, not only in the context of adaptation, but also professionalization, professional self-determination, in General. This research is aimed at solving this problem, which is aimed at studying the features of socio-perceptual properties of students with different levels of mathematical abilities. 

Cognitive Research in Science, Engineering and Education (IJCRSEE), (8), Special issue of Current Research and Trends in Cognitive Sciences 2020, 103-112.

\section{Materials and Methods}

The study sample consisted of 76 students of natural science majors aged 17 to 23 years $(M=19.8$; $\mathrm{SD}=3.2(58 \%$ male) $)$.

The research methods were: testing, expert evaluation, survey method, statistical methods (W-Kendall, tay-b Kendall, Mann Whitney U test, Chi-squared test, Spearman rank correlation coefficient). The methodological tools are presented by the following methods: 1) to diagnose mathematical abilities, a test of analytical mathematical abilities was used (Abakumova and Babiyants, 2012); subtests of the "Intellect structure Test (TSI)" were used. Amthauer, namely: subtest 5 "Arithmetic problems" (assessment of the level of development of practical mathematical thinking, mathematical generalization abilities), subtest 6 "Numerical series" (analysis of inductive thinking, the ability to operate numbers, analytical and synthetic mathematical abilities), subtest 7 "Spatial imagination" (research of combinatorial abilities, the ability to operate images in two-dimensional space), subtest 8 "Spatial generalization" (assessment of the ability to operate spatial images and generalize relations between them); 2) the diagnosis of subjective variables was carried out using the procedure of self-assessment of intelligence; a questionnaire to identify giftedness in a particular area (Krutetskiy, 1998); 3) for the diagnosis of social-perceptual properties, the method of social intelligence research by J. Guilford and M. Sullivan, adapted by Mikhailova (1996); the questionnaire of emotional intelligence by D. V. Lyusin (Belova, 2004) was used.

The study assumed the following tasks: to form a representative sample of the study, including expert evaluation of mathematical ability; undertake a comparative analysis of the characteristics of concepts about their cognitive interest, self-evaluations of intelligence and socio-perceptional properties of students with different levels of mathematical ability; to perform the relationship of mathematical ability and social-perceptual properties; to determine the location of findings in the system of modern scientific knowledge. Two assumptions were made: 1) students with different levels of mathematical abilities may have different features of subjective ideas about their cognitive interests, self-assessment of intelligence and socio-perceptual properties; 2) mathematical abilities may be interrelated with socio-perceptual properties (for example, student age).

The indicated failure of the test approach in the identification of abilities (including mathematical) (Bogoyavlenskaya, 2010; Kolmogorov, 2001; Shadrikov, 2019; Yurkevich, 2009: Al-meida et al, 2016), brought the inclusion of the procedure of expert evaluation in the study. The experts were employees of the University teaching of disciplines of a mathematical cycle IC in study groups of students. In total, three employees with academic degrees were involved. The Working concept of giftedness indicates that in the process of identifying giftedness, an expert assessment of activities is necessary, where experts must have high qualifications in the field of activity under study, and the assessment must take into account not only the current level of development of the property, but also the zone of nearest development (Bogoyavlenskaya, 2004). Therefore, the involvement of experts who lead the learning process of the studied students is justified.

Experts were asked to evaluate the students ' abilities on a 5-point scale: 1) the ability to generalize mathematical material, isolate the main thing, distracting from the unimportant, to see the General in externally different; 2) the ability to operate with numerical and symbolic symbols (Krutetskiy, 1998). Further, the degree of consistency of experts 'opinions was revealed (W-Kendall), which showed that a high degree of consistency of experts' opinions was found in the average assessment of respondents' mathematical abilities $\left(W=0.219 ; X^{2}=54.672, p=0.000\right)$. The Confidence interval of generalized expert assessments was 4.08>M>2.7, which allowed us to divide the sample into three groups (high $(7.1 \%)$, medium (22.9\%), and low (70\%) level of mathematical abilities).

The results of the test "Analytical mathematical abilities" showed that $26.3 \%$ of the surveyed students have an average level of analytical mathematical abilities, while $73.7 \%$ have a low level. Thus, the results of expert evaluation and testing are generally the same, which is confirmed by correlation analysis (tay- $b$ Kendall; $r=0.561, p=0.000$ ). In the further analysis, the test results were selected as the basis for dividing the sample into groups based on the level of mathematical abilities: group 1 (average level of analytical mathematical abilities), group 2 (low level of analytical mathematical abilities).

The ability to conduct a comparative analysis of non-numerical groups is due to the calculation of the confidence zone of expert assessment values, in which the mathematical expectation of the process is located with a certain probability (Sukhodolsky, 2008). In addition, statistical studies indicate that the sample size depends on the rarity of objects (Sukhodolsky, 2008). Data on the parameters of the ideal General population of mathematically gifted students is not provided, so an expert assessment was additionally used, which showed a shift in the distribution to the left. Given the size of one of the subgroups, only nonparametric criteria and correlation coefficients were used in the analysis, the calculation of which 


\section{is based on ranks.}

Data analysis was performed as follows: 1) selection of experts and criteria for expert evaluation, statistical analysis of the results of expert evaluation, comparison of the results of expert evaluation and testing results, and making a decision on the basis of dividing the empirical group into samples; 2) analysis of differences in the characteristics of subjective representations about their cognitive interests, selfassessment of intelligence and socio-perceptual properties in students with different levels of analytical mathematical abilities: 3 ) analysis of the relationship between mathematical abilities and socio-perceptual properties. The study can be described as an empirical one, carried out in the concept of the cross-section method.

\section{Results}

First, a comparative analysis of the self-assessment of intelligence was conducted. It was found (Chi-squared test) that the self-assessment of intelligence differs in students with average and low levels of analytical mathematical abilities $\left(X^{2}=8.671, p=0.013\right)$. Obtained the following frequency distribution: 1$)$ respondents group 1 your intelligence at a high level $(25 \%, n=5)$, average $(50 \%, n=10)$, low $(25 \%, n=5)$; 2 ) respondents of group 2 rate your intelligence on a high level $(26.8 \%, n=15)$ and average (17.9 percent, $n=10)$, high (55.4 per cent, $n=31)$. Students with an average level of analytical mathematical abilities are more likely to rate their intelligence as average, students with a low level of analytical mathematical abilities are more likely to rate their intelligence as high.

The analysis of subjective ideas about their cognitive interests (Chi-squared test) showed that there is a tendency to show differences in students with different levels of analytical mathematical abilities $\left(X^{2}=14.157, p=0.028\right)$. The frequency distribution of the group 1 respondents ' choices is represented by a sequence: artistic activity $(30 \%, n=6)$, mathematics and mechanics $(25 \%, n=5)$, Humanities $(25 \%, n=5)$, nature $(20 \%, n=4)$. The sequence of respondents in group 2 is as follows: Humanities $(33.9 \%, n=19)$, art $(25 \%, n=14)$, sports $(14.3 \%, n=8)$, communication interests $(10.7 \%, n=6)$, mathematics and mechanics $(8.9 \%, n=5)$, nature $(3.6 \%, n=2)$, labor $(3.6 \%, n=2)$.

Subjective ideas about students 'own cognitive interests with an average level of analytical mathematical abilities have a less differentiated structure. Students with a low level of analytical mathematical abilities have more differentiated subjective perceptions of their own cognitive interests and have preferred fields of activity.

Statistical analysis of component and composite assessment of social intelligence (table 1) showed that students with different levels of mathematical ability composite assessment of social intelligence and the ability to recognize the structure of interpersonal situations in dynamics, the ability to correctly estimate the state, feelings, people's intentions for their non-verbal manifestations. The ability to correctly assess people's States, feelings, and intentions based on their nonverbal expressions tends to show differences. All these scales of social intelligence are more pronounced in students with an average level of analytical mathematical abilities.

Statistical analysis of the ability to empathize (Table 1) showed that students with different levels of mathematical abilities have differences in the emotional channel of empathy, intuitive channel of empathy, and there is a tendency to show differences in the overall level of empathy. All these empathy scales are more pronounced in students with a low level of analytical mathematical abilities.

There were no differences in the components of emotional intelligence among students with different levels of mathematical abilities. 
Tushnova A., Y. (2020). Features of social-perceptual properties of mathematically gifted students, International Journal of Cognitive Research in Science, Engineering and Education (IJCRSEE), (8), Special issue of Current Research and Trends in Cognitive Sciences 2020, 103-112.

Table 1

Comparative analysis of social intelligence and empathy of students with different levels of mathematical abilities

\begin{tabular}{|c|c|c|c|c|}
\hline Variables & Group 1 & Group 2 & $\begin{array}{c}\text { Mann Whitney } \\
\text { U }\end{array}$ & p-Value \\
\hline & $\mathrm{M}(\mathrm{SD})$ & $\mathrm{M}(\mathrm{SD})$ & & \\
\hline Ability to anticipate the consequences of behavior & $8,5(2,4)$ & $8,2(3,1)$ & 556 & 0,962 \\
\hline $\begin{array}{l}\text { The ability to properly evaluate the condition on the non-verbal } \\
\text { manifestations }\end{array}$ & $8,8(1,5)$ & $7,7(1,9)$ & 370,5 & 0,023 \\
\hline Verbal expression & $8,4(1,7)$ & $7,8(1,9)$ & 458,5 & 0,224 \\
\hline $\begin{array}{l}\text { Ability to recognize the structure of interpersonal situations in dy- } \\
\text { namics }\end{array}$ & $8,1(1,9)$ & $5,98(2,1)$ & 245 & 0,000 \\
\hline Comprehensive assessment of social intelligence & $34,1(3,7)$ & $29,7(5,2)$ & 258,5 & 0,000 \\
\hline Rational channel of empathy & $4,2(1,3)$ & $4,1(1,1)$ & 522 & 0,643 \\
\hline Emotional channel of empathy & $2,6(1,4)$ & $4,1(1,3)$ & 239 & 0,000 \\
\hline Intuitive channel of empathy & $2,6(1,8)$ & $4(1,5)$ & 335 & 0,007 \\
\hline Attitudes to empathy & $3,2(1,6)$ & $3,2(1,6)$ & 559,5 & 0,995 \\
\hline Penetrating power in empathy & $3,4(1,98)$ & $3,3(1,89)$ & 545 & 0,858 \\
\hline Identification in empathy & $3,5(2,2)$ & $3,5(1,95)$ & 555 & 0,952 \\
\hline General level of empathy & $19,3(5,2)$ & $22,7(4,1)$ & 380,5 & 0,034 \\
\hline
\end{tabular}

To test the hypothesis of the relationship between mathematical abilities and social-perceptual properties (on the example of student age), a correlation analysis (r-Spearman) was conducted, the results of which allowed us to identify significant relationships between mathematical abilities and components of social intelligence, types and channels of empathy, as well as components of emotional intelligence (Table 2).

\section{Table 2}

Results of correlation analysis of mathematical abilities and socio-perceptual properties

\begin{tabular}{|c|c|c|c|}
\hline \multicolumn{2}{|l|}{ Variables } & \multirow[t]{2}{*}{ r-Spearman } & \multirow[t]{2}{*}{$\mathrm{p}$-Value } \\
\hline Mathematical skills & $\begin{array}{l}\text { Socio-perceptual } \\
\text { properties }\end{array}$ & & \\
\hline \multirow{3}{*}{$\begin{array}{l}\text { Subtest } 5 \text { (TSI) "Arithmetic tasks" (assessment of the level of } \\
\text { development of practical mathematical thinking, mathematical } \\
\text { generalization abilities) }\end{array}$} & Verbal expression (SI 1) & 0,252 & 0,028 \\
\hline & General level of empathy & 0,308 & 0,007 \\
\hline & $\begin{array}{l}\text { Overall level of emotional } \\
\text { intelligence }\end{array}$ & 0,337 & 0,003 \\
\hline $\begin{array}{l}\text { Subtest } 6 \text { (TSI) "Numerical series "(analysis of inductive thinking, the } \\
\text { ability to operate with numbers, analytical-synthetic mathematical } \\
\text { abilities) }\end{array}$ & $\begin{array}{l}\text { Emotional channel of } \\
\text { empathy }\end{array}$ & 0,254 & 0,027 \\
\hline \multirow{4}{*}{$\begin{array}{l}\text { Subtest } 7 \text { (TSI) "Spatial imagination" (the study of combinatorial } \\
\text { abilities, the ability to operate images in two-dimensional space) }\end{array}$} & Expression control (EI2) & 0,239 & 0,038 \\
\hline & $\begin{array}{l}\text { Understanding emotions } \\
\text { (EI2) }\end{array}$ & 0,257 & 0,025 \\
\hline & Overall level of emotional & & \\
\hline & intelligence & 0,341 & 0,003 \\
\hline \multirow{2}{*}{$\begin{array}{l}\text { Subtest } 8 \text { (TSI) "Spatial generalization" (assessment of the ability to } \\
\text { operate with spatial images and generalize the relationships between } \\
\text { them) }\end{array}$} & Verbal expression (SI 1) & 0,278 & 0,015 \\
\hline & $\begin{array}{l}\text { Intuitive channel of em- } \\
\text { pathy }\end{array}$ & 0,223 & 0,053 \\
\hline
\end{tabular}
level of 0.05 .

Notation: 1 - SI - social intelligence, 2 - El - emotional intelligence. * is the significance level of $0,01,{ }^{* *}$ a significance 
Based on the results of correlation analysis, we can conclude that all identified correlations are positive. Subtest 5 (TSI) has the relationships with socio-perceptual properties, namely, verbal expression $(p=0.05)$, General level of empathy $(p=0.01)$, General level of emotional intelligence $(p=0.01)$.. We see that the higher the level of practical mathematical thinking and mathematical generalization ability, the higher the ability to understand speech expression in the context of specific relationships, the greater the repertoire of role behavior. The overall level of empathy is also higher. It is shown that the ability of mathematical generalization is associated with the General level of emotional intelligence, that is, the ability to understand and manage their own and other people's emotions.

Analytical and synthetic mathematical abilities (Subtest $6(\mathrm{TSI})$ ) they tend to show a relationship with the emotional channel of empathy $(p=0.05)$. That is, the higher the analytical and synthetic mathematical abilities are developed (the process from the particular to the General), the higher the ability to emotionally tune in to the other, to participate and empathize with the other.

Subtest 7 (TSI) is related to the overall level $(p=0.01)$ and components of emotional intelligence (expression control $(p=0.05)$, emotion understanding $(p=0.01)$ ). High indicators of combinatorial abilities, the ability to operate images in two-dimensional space are associated with a high level of ability to understand and manage emotions, namely, the ability to understand their own and others' emotions and the ability to control the external manifestations of their emotions. In other words, the development of the ability to accurately perceive the shape and size of planar figures (linear eye), mental operation of images is associated with the development of the ability to understand and control emotions. Understanding includes individual and interpersonal aspects, while control is only individual.

Subtest 8 (TSI) "Spatial generalization" is related to the social intelligence component verbal expression $(p=0.01)$ and the intuitive empathy channel $(p=0.05)$. This ability is closely related to visualimaginative thinking and involves operating images in three-dimensional space. The higher the ability to operate with spatial images and generalize the relationship between them, the more developed the ability to understand speech expression in the context of specific relationships, the greater the use of emotional responsiveness as a means of "adjustment" to the partner, in General, the higher the emotional responsiveness.

\section{Discussions}

Summarizing the results of an empirical analysis aimed at testing the hypothesis that students with different levels of analytical mathematical abilities may have different features of subjective representations of their cognitive interests, self-assessment of intelligence and socio-perceptual properties, we can conclude that it is partially confirmed. The study shows that students with average and low levels of analytical mathematical abilities have differences in the subjective variables "self-assessment of intelligence" and "subjective ideas about their cognitive interests". Students with an average level of analytical mathematical abilities are characterized by an average self-esteem of intelligence, and equal shares of high and low self-esteem of intelligence. Subjective ideas about their own cognitive interests of this group have a small degree of differentiation and are represented by artistic activities, mathematics and mechanics, the Humanities and nature. Students with a low level of analytical mathematical abilities are characterized by a predominance of low self-esteem of intelligence. Subjective ideas about their own cognitive interests in this group are more differentiated, but the most preferred are the humanitarian sphere and artistic activities.

The literature presents research on the self-esteem of the gifted teens. So, Tsoi and Scheblanova (2013) we described the age and gender characteristics of self-assessment of intelligence by older teenagers (grade 8 and 9 ). It is shown that the self-assessment of intelligence students 8 th grade higher than students of grade 9 girls higher rate of verbal-linguistic skills, intra - and interpersonal, boys, mathematics and natural science (Tsoi and Scheblanova, 2013). In descriptions of General characteristics of self-esteem of gifted children, it is noted that low self-esteem can hinder the implementation of abilities and adaptation of gifted children depends on the level of intelligence (Bogoyavlenskaya, 2004; Leites, 2008; Yurkevich, 2011). In this regard, the average self-assessment of intelligence by students with an average level of mathematical abilities can be designated as realistic, contributing to effective social adaptation.

The composite assessment of social intelligence and the ability to recognize the structure of interpersonal situations in dynamics in students with an average level of analytical mathematical abilities is higher than in group 2. Also, in this group, there is a tendency to have the ability to assess the state of people by non-verbal manifestations. It should be noted that according to the test norms (Belova, 2004), 
the values in both groups are characterized as the average sample norm. Analyzing the above results, it is necessary to take into account the idea of a small relationship between general and social intelligence (Belova, 2004), that mathematical abilities are not intelligence in total (Khertanova and Kondaurova, 2006), as well as the fact that the realization of the potential of giftedness is associated with successful interpersonal interaction (Bogoyavlenskaya, 2004; Davidson, 2009; Kolmogorov, 2001; Renzulli, 2002, 2005). Higher values of social intelligence in students with a higher level of mathematical abilities indicate the prospects for research, namely, the study of the relationship of social intelligence with objective and subjective assessments of mathematical giftedness. Detailing the results allows us to note that verbal expression (a component of social intelligence) is associated with practical mathematical thinking, the ability of mathematical and spatial generalization.

There are differences in the emotional channel of empathy, the intuitive channel of empathy in students with different levels of mathematical abilities, and there is a tendency to show differences in the overall level of empathy. The quantitative values of these indicators are higher for group 2 respondents. That is, students with a low level of analytical mathematical abilities have more emotional responsiveness and the ability to make a forecast of behavior on this basis, as well as they have a more developed ability to predict the behavior of a partner in conditions of lack of objective information, based on their own experience. The overall level of empathy is also higher for students with low math abilities. At the same time, according to the test standards, this group corresponds to the average sample rate (Boyko, 1996). At the same time, students with an average level of mathematical ability showed an understated level of empathy.

Bovina (2020) points out that empathy is considered more often as a personal construct, but understanding empathy as a mechanism of social perception would allow resolving conceptual contradictions in the study of this phenomenon. Batson (2009) systematizing research on empathy in the fourth model of conceptualization of empathy speaks about projecting oneself into the situation of another person. Bovina (2020) notes that in imitation theory, empathy involves understanding the thoughts and feelings of another, based on one's own mental model. According to Rimé (2009) the emergence of empathy is based on cognitive processes (Bovina, 2020, p. 91). in other words, the identified relationships of empathy and analytical-synthetic mathematical abilities, mathematical and spatial generalization abilities, in the prospects of the study set the task of studying models and determinants of the process of understanding the other.

The revealed relationships of emotional intelligence with practical mathematical thinking, mathematical generalization and combinatorial abilities make it relevant to address modern research on emotional intelligence. It is shown that a high level of emotional intelligence increases the level of subjective well-being (Por et al, 2011), is positively associated with life satisfaction, self-esteem and self-acceptance (Carmeli et al, 2009), and readiness for online learning (Alenezi, 2020). Djermanov and Marić Jurišin (2018) point out the importance of emotional literacy in education and the need for pedagogical monitoring of the emotional development of young people, the development of their emotional competence directly in the system of education. We can assume that mathematical abilities will positively influence the subjective well-being of students, which coincides with the thesis described above about the relationship of mathematical giftedness with life fulfillment (Krasnoryadtseva, 2013). The current format of online education and its connection with emotional intelligence in this study allows us to make a primary assumption about the greater readiness of mathematically gifted students for this format of education.

\section{Conclusions}

The results of the study showed that: 1) students with different levels of mathematical abilities have differences in the features of subjective ideas about their cognitive interests, self-assessment of intelligence, composite assessment of social intelligence, the ability to recognize the structure of interpersonal relationships in dynamics, emotional and intuitive channel of empathy; 2) students with different levels of mathematical abilities have tendencies to show differences in the ability to correctly assess States based on non-verbal manifestations and the General level of empathy; 3 ) discovered a positive relationship with different levels of significance practical mathematical thinking, and math skills generalization with verbal expression, overall level of empathy, the overall level of emotional intelligence; analytic-synthetic mathematical abilities and emotional channel of empathy; combinatorial abilities, ability to handle images in two-dimensional space with the overall level and components of emotional intelligence (control of expression, understanding emotions); ability to operate with spatial images and generalize relationships between them with verbal expression and intuitive channel of empathy. 
In summary, we can generalize the features of socio-perceptual properties of students with different levels of mathematical abilities. Students with an average level of analytical mathematical ability have a more realistic self-assessment of intelligence. Their subjective ideas about their own cognitive interests are little differentiated and are distributed among three spheres, where the mathematical has an equal percentage with the humanitarian. The higher expression of the General indicator of social intelligence than in the group with a low level of mathematical abilities is explained by high indicators of the ability to recognize the structure of interpersonal situations in dynamics and assess States by non-verbal manifestations.

The greater severity of the overall indicator of social intelligence than in group 2 is justified by indicators of the ability to recognize the structure of interpersonal situations in dynamics and evaluate States by non-verbal manifestations. Conditionally, these results can be described as a more pronounced ability to predict behavior based on a cognitive analysis of dynamic and nonverbal characteristics. This may be due in a certain way to the fact that students with an average level of analytical mathematical abilities have an underestimated level of empathy. When building programs of psychological and pedagogical support for this category of students, it is necessary to take into account the dominance of the cognitive component of forecasting over the emotional one. Since the unspoken ability to predict the partner's behavior through emotional responsiveness may be a factor of impaired social adaptation in the educational and professional group.

Students with low analytical math skills are more likely to show low self-esteem of intelligence. At the same time, they have a more differentiated field of subjective ideas about cognitive interests, where the leading ones are the humanitarian and artistic spheres. The social intelligence of this group corresponds to the average sample rate. When organizing psychological and pedagogical support for this category of students, it is recommended to include a module on the development of social intelligence in the program. This observation is also true for the group with an average level of analytical mathematical abilities.

The found relationships between mathematical abilities and social-perceptual properties indicate that a greater number of relationships with social-perceptual properties have the ability of mathematical generalization and practical mathematical thinking. Here, we found relationships not only with empathy, but also the ability to recognize verbal expression and the General ability to understand and manage their own and others 'emotions. The ability to operate images in two-dimensional space is related only to the level and components of emotional intelligence. This is significant in comparison with the ability to operate images in three-dimensional space, which are interconnected with social intelligence and empathy, but are formed earlier in ontogenesis. It can be assumed that in this way, the recognition and control of emotions is associated with more complex forms of mathematical thinking.

The prospects of this research are: improving the procedure for expert evaluation of mathematical giftedness; studying the components of mathematical abilities that determine socio-perceptual features; expanding the repertoire of socio-perceptual properties in the study; creating and testing a program of psychological and pedagogical support for mathematically gifted students.

\section{Acknowledgments}

The authors are grateful to all participants in the research and to the editorial team for their kind and professional assistance.

Conflict of interests

The author declares no conflict of interest.

\section{References}

Abakumova, I. V. \& Babiyants, K.A. (2012). Диагностика математической одаренности [Diagnostics of mathematical giftedness]. Southern Federal University, Rostov-on-don. Retrieved from https://talant-portal.sfedu.ru/sites/default/ files/diagnostika_matematicheskoy_odarennosti_abakumova_babiyanc.pdf

Alenezi, A. M. (2020). The relationship of students' emotional intelligence and the level of their readiness for online education: A contextual study on the example of university training in Saudi Arabia. The Education and Science Journal, 22(4), 89-109. http://dx.doi.org/10.17853/1994-5639-2020-4-89-109

Almeida, L. S., Araújo, A. M., Sainz-Gómez, M., \& Prieto, M. D. (2016). Challenges in the identification of giftedness: Issues related to psychological assessment. Anales de psicología, 32(3), 621-627. http://dx.doi.org/10.6018/analesps.32.3.259311

Andreyeva, G.M. (2000). Психология социального познания [The psychology of social cognition]. Aspekt press, Moscow. Retrieved from https://search.rsl.ru/ru/record/01002568601 
Tushnova A., Y. (2020). Features of social-perceptual properties of mathematically gifted students, International Journal of Cognitive Research in Science, Engineering and Education (IJCRSEE), (8), Special issue of Current Research and Trends in Cognitive Sciences 2020, 103-112.

Ashcraft, M. H., \& Krause, J. A. (2007). Working memory, math performance, and math anxiety. Psychonomic bulletin \& review, 14(2), 243-248. https://doi.org/10.3758/BF03194059

Ayres, P. L. (2001). Systematic mathematical errors and cognitive load. Contemporary Educational Psychology, 26(2), 227248.

Batson, C. D. (2009). These things called empathy: Eight related but distinct phenomena. In J. Decety \& W. Ickes (Eds.), Social neuroscience. The social neuroscience of empathy (p. 3-15). MIT Press. https://doi.org/10.7551/ mitpress/9780262012973.003.0002

Belova, S.S. (2004). Социальный интеллект: сравнительный анализ методик измерения [Social intelligence: a comparative analysis of measurement techniques]. In D. V. Lyusin \& D. V. Ushakov (Eds.), Social intelligence: theory, measurement, research (pp. 109-119). Institute of psychology of the Russian Academy of Sciences, Moscow. Retrieved from https:// elibrary.ru/item.asp?id=21688471

Bogoyavlenskaya, D.B. \& Nizovtsova, A.N. (2017). К проблеме соотнесения общих, специальных и творческих способностей (на примере математической одаренности) [To the problem of correlation of General, special and creative abilities (on the example of mathematical giftedness)]. Psychology. Journal of the higher school of Economics, 14(2), 277-297. https://doi.org/10.17323 / 1813-8918-2017-2-277-297

Bogoyavlenskaya, D.B. (2004). Рабочая концепция одаренности [Working concept of giftedness]. Education issues, (2), 46-68. https://doi.org/10.24412/FhFzuzYI9AA 4

Bogoyavlenskaya, D.B. (2010). Одаренность: ответ через полтора столетия [Giftedness: the answer in a century and a half]. Vestnik of Moscow state University Psychology, (3), 3-18. URL: https://cyberleninka.ru/article/n/odarennost-otvetcherez-poltora-stoletiya.

Bovina, I. B. (2020). Empathy: Critical Analysis and New Research Perspectives. Cultural-Historical Psychology, 16(1), 88-95. https://doi.org/10.17759/chp.2020160109

Boyko, V.V. (1996). Энергия эмоций в общении: взгляд на себя и на других [Emotional energy in communication: looking at yourself and others]. Informational-publishing house "Filin", Moscow. Retrieved from https://search.rsl.ru/ru/ record/01001756600

Campbell, J. I., \& Xue, Q. (2001). Cognitive arithmetic across cultures. Journal of Experimental Psychology: General, 130(2), 299-315. https://doi.org/10.1037/0096-3445.130.2.299

Carmeli, A., Yitzhak-Halevy, M., \& Weisberg, J. (2009). The relationship between emotional intelligence and psychological wellbeing. Journal of Managerial Psychology, 24(1), 66-78. https://doi.org/10.12691/rpbs-2-4-2

Davidson, J. E. (2009). Contemporary models of giftedness. In International handbook on giftedness (pp. 81-97). Springer, Dordrecht. https://doi.org/10.1007/978-1-4020-6162-2_4

Djermanov, J., \& Marić Jurišin, S. (2018). Students' emotional literacy in the discourse of the contemporary school in Serbia. International Journal of Cognitive Research in Science, Engineering and Education (IJCRSEE), 6(2), 1-10. https://doi. org/10.5937/ijcrsee1802001D

Druzhinin, V.N. (2000). Природа одаренности [Nature of giftedness]. In D. V. Ushakov (Eds.), Psychology of giftedness from theory to practice (issue 2, pp. 15-25). Institute of psychology of the Russian Academy of Sciences, Moscow.

Hanin, V. \& Van Nieuwenhoven, C. (2020). An Exploration of the Cognitive, Motivational, Emotional and Regulatory Behaviours of Elementary-School Novice and Expert Problem Solvers. Canadian Journal of Science, Mathematics and Technology Education, 20, 312-341. https://doi.org/10.1007/s42330-020-00092-9

Kanin, E. S. (2013). Математические способности учащихся и их развитие. [Students' mathematical abilities and their Development]. Bulletin of Vyatka state University, (2-1), 152-158. Retrieved from https://cyberleninka.ru/article/n/ matematicheskie-sposobnosti-uchaschihsya-i-ih-razvitie

Khertanova, V.V., \& Kondaurova, I. K. (2006). Развитие математическихспособностейипознавательнойсамостоятельности студентов в контексте их будущей профессиональной деятельности [Development of mathematical abilities and cognitive independence of students in the context of their future professional activity]. Bulletin of the Saratov state technical University, 3(2), 260-264. Retrieved from https://elibrary.ru/author_items.asp?authorid=555978\&pubrole=10 $0 \&$ show refs $=1 \&$ show option $=0$

Kholodnaya, M. А. (2011). Эволюция интеллектуальной одаренности от детства к взрослости: эффект инверсии развития [The evolution of intellectual giftedness from childhood to adulthood: the effect of inversion development]. Psychological journal, 32(5), 69-78. Retrieved from http://www.ipras.ru/engine/documents/document3358.pdf

Khinchin, A. Үa. (1961). О воспитательном эффекте уроков математики [On the educational effect of math lessons]. Mathematical education, 6, 7-28. Retrieved from http://www.mathnet.ru/links/f69d82f69f09afcfd78726a710ca3b20/mp676. pdf

Kolmogorov, A. N. (2001). О развитии математических способностей (письмо В.А.Крутецкому) [On the development of mathematical abilities (letter to V. A. Krutetsky)]. Questions of psychology, 3, 103-106. Retrieved from https://elibrary. ru/item.asp?id=15499930

Krasnoryadtseva, О. М. (2013). Актуализация потенциала одаренности подростков с выраженным интересом к математике: возможности психолого-образовательных технологий [Actualization of the potential of gifted adolescents with a pronounced interest in mathematics: the possibilities of psychological and educational technologies]. Siberian psychological journal, 48, 39-47. Retrieved from https://cyberleninka.ru/article/n/aktualizatsiya-potentsialaodarennosti-podrostkov-s-vyrazhennym-interesom-k-matematike-vozmozhnosti-psihologo-obrazovatelnyh

Krutetskiy, V. А. (1998). Психология математических способностей школьников [Psychology of mathematical abilities of schoolchildren]. Institute of practical psychology, Moscow. Retrieved from https://search.rsl.ru/ru/record/01000581254

Kryukova, Е. А. (2001). Математическая одаренность: индивидуальные, гендерные и возрастные особенности: дис. ... канд. психол. наук: 19.00.01. [Mathematical giftedness: individual, gender and age characteristics: dis. ... Cand. the course of studies. Sciences: 19.00.01.]. (Doctoral dissertation, Пермский государственный гуманитарнопедагогический университет). Perm. Retrieved from https://search.rsl.ru/ru/record/01002308503

Kunitsyna, V. N. \& Kazarinova, N. V. \& Pogol'sha, V. М. (2001). Межличностное общение [Interpersonal communication]. Peter, Saint Petersburg. Retrieved from https://search.rsl.ru/ru/record/01000707877

Leites, N. S. (2008). Возрастная одаренность и индивидуальные различия [Age-related giftedness and individual 
Tushnova A., Y. (2020). Features of social-perceptual properties of mathematically gifted students, International Journal of Cognitive Research in Science, Engineering and Education (IJCRSEE), (8), Special issue of Current Research and Trends in Cognitive Sciences 2020, 103-112.

differences]. Moscow psychological and social Institute, Moscow. Retrieved from https://search.rsl.ru/ru/ record/01004244555

Mikhailova, E.S. (1996). Методика исследования социального интеллекта: Адаптация теста Дж. Гилфоорда и М. Салливена: Руководство по использованию [Social intelligence research methodology: Adapting the J. Guilford and M. Sullivan test: A guide to use]. Imaton, Saint Petersburg.

Por, J., Barriball, L., Fitzpatrick, J., \& Roberts, J. (2011). Emotional intelligence: Its relationship to stress, coping, well-being and professional performance in nursing students. Nurse education today, 31(8), 855-860. https://doi.org/10.1016/j. nedt.2010.12.023

Renzulli, J. S. (2002). Expanding the conception of giftedness to include co-cognitive traits and to promote social capital. Phi Delta Kappan, 84(1), 33-58. https://doi.org/10.1177/003172170208400109

Renzulli, J. S. (2005). The three-ring conception of giftedness. In R. J. Sternberg \& J. E. Davidson (Eds.), Conceptions of giftedness ( $2^{\text {nd }}$ ed., pp. 246-279). New York: Cambridge University Press. https://doi.org/10.1017/CBO9780511610455.015

Ridetskaya, О. G. (2011). Психология одаренности [Psychology of giftedness]. Publishing center of the Eurasian open Institute, Moscow. Retrieved from https://search.rsl.ru/ru/record/01005418330

Rimé, B. (2009). Le partage social des émotions [Social sharing of emotions]. Presses Universitaires de France, Paris. https:/l doi.org/10.1016/j.jtcc.2011.01.003

Рыжов, В. В. (1981). О взаимосвязи особенностей общения личности и ее социально-перцептивных характеристик [On the relationship between personality communication features and its socio-perceptual characteristics]. Bonpocbl психологии, (2), 58-67. Retrieved from http://www.voppsy.ru/issues/1981/812/812058.htm

Sari Faradiba, S., Sa'dijah, C., Parta, N., \& Rahardjo, S. . (2019). Looking without seeing: the role of metacognitive blindness of student with high math anxiety. International Journal of Cognitive Research in Science, Engineering and Education (IJCRSEE), 7(2), 53-65. https://doi.org/10.5937/IJCRSEE1902053F

Schoevers, E. M., Kroesbergen, E. H., \& Kattou, M. (2020). Mathematical creativity: A combination of domain-general creative and domain-specific mathematical skills. The Journal of Creative Behavior, 54(2), 242-252. https://doi.org/10.1002/ jocb.361

Shadrikov, V. D. (2019). К новой психологической теории способностей и одаренности [To a new psychological theory of ability and giftedness]. Психологический журнал, 40(2), 15-26, https://doi.org/10.31857/S020595920002981-5

Sternberg, R. J. (2000). Giftedness as developing expertise. In K. A. Heller, F. J. Monks, R. J. Sternberg, \& R. F. Subotnik (Eds.), International handbook of giftedness and talent ( $2^{\text {nd }}$ ed., pp. 55-66). New York, Elsevier. https://doi.org/10.1016/ B978-008043796-5/50004-8

Sukhodolsky, G. V. (2008). Математические методы в психологии [Mathematical methods in psychology]. Publishing house of the Humanitarian center ( $3^{\text {nd }}$ ed.), Moscow.

Tsoi, A.B. \& Scheblanova, Е.И. (2013). Самооценка интеллекта одарённых учащихся разного возраста и пола [Selfassessment of the intelligence of gifted students of different ages and genders]. Начальная школа плюс До и После, (5), 19-23. Retrieved from http://www.school2100.ru/upload/iblock/d1c/Tsoj.pdf

Ushakov, D. V. (2011). Психология интеллекта и одаренности [Psychology of intelligence and giftedness]. Institute of Psychology, Russian Academy of Education, Academy of Sciences, Moscow. Retrieved from https://search.rsl.ru/ru/ record/01005369428

Yurkevich, V.S. (2009). Одаренные дети и интеллектуально-творческий потенциал общества [Gifted children and the intellectual and creative potential of society]. Psychological Science \& Education, (4), 74-86. Retrieved from https:// psyjournals.ru/psyedu/2009/n4/24496.shtml

Yurkevich, V.S. (2011). Одаренные дети: сегодняшние тенденции и завтрашние вызовы [Gifted children: today's trends and tomorrow's challenges]. Psychological Science \& Education, (4), 99-108. Retrieved from https://psyjournals.rul files/48678/psyedu_2011_n4_Yurkevich.pdf 